\title{
Selection of Plant Cell Lines with Enhanced Chilling Resistance
}

\author{
P. J. DIX and H. E. STREET \\ Botanical Laboratories, Untoersity of Leicester, Letcester LE1 7RH
}

Received: 31 December 1975

\begin{abstract}
Cell cultures of Nicotiana sylvestris and Capsicum annum, both without and following exposure to the mutagen, EMS, have been submitted to chilling for 21 days at $-3{ }^{\circ} \mathrm{C}$ and $+5^{\circ} \mathrm{C}$ respectively and the cell lines derived from the surviving cells tested for their subsequent resistance to the chilling treatment. Some of the cell lines when again submitted to the chilling stress showed no enhanced survival, others retained their resistance after an extended period of growth at $24^{\circ} \mathrm{C}$. The application of the mutagen promoted the isolation of such stable resistant cell lines. Studies of the response of the respiratory activity of isolated mitochondria to temperature from a resistant and from a sensitive cell line of $C$. annuum revealed a difference similar to that previously reported from studies on isolated mitochondria from chilling-sensitive and chilling-resistant plants of various species.
\end{abstract}

\section{INTRODUCTION}

The potential of plant tissue and cell cultures for effecting genetic modification has been stressed in a number of recent papers (Binding, 1974; Heyn, Rörsch and Schilperoort, 1974, Street, 1975). One approach to such genetic modification involves the isolation of stable variant cell lines from established cell cultures either directly or following mutagen treatment, regeneration of plants from such lines and study of the phenotypic expression of the genetic variants. The isolation of variant cell lines requires that the cells be subjected to appropriate selection pressures and to this end we have used exposure to high salt concentration (Dix and Street, 1975), high temperature and chilling temperatures, and have tested for retention of the resistance following growth in absence of the environmental stress. The work now described relates to the isolation of chilling-resistant cell lines of Nicotiana sylvestris and Capsicum annum and to the demonstration of a differential temperature response in the respiration of mitochondria isolated from a chilling-resistant and a chilling-sensitive cell line of $C$. annum probably related to a phase change in the lipid component of their membranes (Lyons, 1972).

\section{MATERIALS AND METHODS}

\section{Origin and propagation of cultures}

Callus cultures were initiated from petioles of haploid (H.9) and diploid (D) Nicotiana sylvestris, Speg and Comes and from diploid (C) Capsicum annum L (var. Canape), transferred to suspension culture, incubated at $25^{\circ} \mathrm{C}$ on the reciprocal shaker and serially subcultured every 21 days as previously described (Dix and Street, 1974). Cell numbers were determined by the method of Henshaw et al (1966).

\section{Plating technique}

For petri dish plating, suspension cultures (7-10 days after subculture) were transferred to 1.0 or $0.6 \mathrm{~mm}$ mesh nylon bolting cloth, the retained cells washed with fresh medium 


\section{4}

and the fine cell suspension passing the filter submitted to a cell count, appropriately diluted and incorporated into agar medium ( 0.9 per cent Oxoid Ionagar No 2) held at $38{ }^{\circ} \mathrm{C}$ to give cell densities in the range $10-50 \times 10^{3}$ cells $\mathrm{ml}^{-1}$. The medium was immediately poured $10 \mathrm{ml}$ per $9 \mathrm{~cm}$ sterile plastic petri dish (Sterilin Ltd) and the dishes sealed with Nescofilm (Bando Chemical Ind. Ltd, Japan) and incubated in the dark.

After incubation the number of colonies (greater than $1 \mathrm{~mm}$ diameter) per plate were counted. The colony count values presented are means based upon counts on 5 or 10 plates.

\section{Selection technique}

Selection of cell lines was by incubation of agar plates for 5 days at $25^{\circ} \mathrm{C}$ followed by transfer to the chilling temperatures $\left(5^{\circ} \mathrm{C}\right.$ for $C$. annurum and $0^{\circ}$ and $-3{ }^{\circ} \mathrm{C}$ for $N$. sylvestris) for 21 days in darkness. Following this chilling period the plates were returned to $25^{\circ} \mathrm{C}$ and incubated for 6 weeks (C. annum ) or 8-10 weeks (N. sylvestris) before counting colonies. The control plated cells were incubated throughout at $25^{\circ} \mathrm{C}$ and colonies counted after 4 weeks (C. annurm) or 6 weeks ( $N$. sylvestris).

In some experiments the suspension cultures were submitted to treatment with a mutagen prior to this selection procedure. The mutagen, ethyl methane-sulphonate (EMS) (Sigma Chemical $\mathrm{Co}$ ) was added aseptically to the suspensions to give known concentrations within the range 0.075 to 1.5 per cent $v / v$, and allowed to act for $60 \mathrm{~min}$. The cells were then collected on fine nylon bolting cloth, washed twice with fresh culture medium, resuspended in medium and the suspensions incubated for 3 days before plating and submission to the selection technique as described above.

Following the selection technique cell lines were obtained by transfer of individual colonies from the plates to $10 \mathrm{ml}$ agar medium in Universal bottles and incubation at $25^{\circ} \mathrm{C}$.

\section{Tests for retention of chilling resistance}

Cell lines isolated as described above were tested for retention of resistance by a callus survival test and by initiating a cell suspension culture and repeating the selection procedure (in absence of the mutagen treatment) described above.

The callus survival test was applied to the cell lines 4 weeks after transfer of the original colonies to the Universal bottles. Each callus piece was cut into small fragments $(0.025-$ $0.050 \mathrm{~g} \mathrm{fr}$.wt) and these implanted in rows (usually three rows of four pieces) on the surface of plates of agar medium. Each cell line was usually represented by eight callus fragments (two rows of four in separate dishes) although in a few instances the number of fragments which could be scored per cell line was reduced to four by contamination. The petri dish plates were immediately sealed and then incubated for 21 days at the chilling temperatures in illuminated refrigerated incubators. Following this the plates were returned to $25^{\circ} \mathrm{C}$ and examined after 6 and 8 weeks ( $N$. sylvestris) or 4 or 6 weeks (C. annurum) and each callus fragment scored as showing survival (fresh white, cream or very pale brown callus growth from all or part of the fragment) or no survival. In the latter case the callus fragment rapidly turned brown or black on return to $25^{\circ} \mathrm{C}$ and no regrowth was observed.

\section{Respiratory activity of isolated mitochondria}

The respiratory activity of mitochondria isolated from cell lines of $C$. annuum (a control line C9 and a variant line CV34) was examined using cells from $500 \mathrm{ml}$ suspension cultures initiated at a cell density of $2 \times 10^{5}$ cells $\mathrm{ml}^{-1}$ and harvested between the 6th and 12th day of incubation. Following harvesting and washing of the cells as described by Wilson (1971), mitochondria were isolated by the method of Raison and Lyons (1970), cell 
disruption being achieved by a $10 \mathrm{~s}$ full-speed treatment with a Polytron homogeniser. Mitochondrial protein was determined by the Folin method as described by Layne (1957). In the measurements of mitochondrial activity not less than $2.0 \mathrm{mg}$ mitochondrial protein was contained in $3 \mathrm{ml}$ reaction medium, and all measurements of respiratory activity commenced within $2 \mathrm{~h}$ of isolation of the mitochondria.

Oxygen uptake by the mitochondria suspended in the reaction medium (Raison and Lyons, 1970) was measured on a Clark-type polargraphic oxygen electrode (Rank Bros, Bottisham, Cambridge) set in a cuvette through which water at controlled temperature was continuously circulated. The temperature of the circulating water was maintained and could be rapidly changed by the combination of a 'U-cool' probe (Nestab Instrument Inc, Portsmouth, N.H., U.S.A.) and a Circotherm II (Shandon Scientific Co Ltd, London). Temperature within the electrode chamber was monitored using a Type $1604 \mathrm{NiCr} / \mathrm{NiAl}$ thermocouple (Comark Electronics Ltd, Rustington, Sussex). Oxygen concentration in the electrode was recorded on a KM Oxygraph (Gilson Medical Electronics, Madison, U.S.A.).

A calibration curve was prepared relating the deflection corresponding to a known volume of oxygen $\left(100 \mu \mathrm{mol} \mathrm{ml}{ }^{-1}\right)$ to temperature over the desired temperature range. This was achieved by releasing a known amount of $\mathrm{O}_{2}$ in the electrode from hydrogen peroxide in presence of excess catalase (Sigma Chemical Co, Kingston-upon-Thames) at a number of temperatures covering the range $5-20{ }^{\circ} \mathrm{C}$.

$0.16 \mathrm{~mm}$ NADH (Sigma Chemical $\mathrm{Co}$ ) was used as substrate and $\mathrm{O}_{2}$ uptake measured in absence of added ADP (state 4) and in presence of excess ADP (700 n mole-Sigma Chemical Co) (state 3) (Chance and Williams, 1955). Preliminary studies at $20^{\circ} \mathrm{C}$ showed respiratory control ratios of 2.1 (cell line $\mathrm{C} \mathrm{9)}$ and 1.9 (CV 34). $\mathrm{O}_{2}$ uptake (state 4 and state 3 ) was then measured at progressively decreasing temperatures each being maintained until a steady state was achieved (3-15 min). Results are presented as Arrhenius plots (the $\log _{10}$ respiration rate $-n$ mole $\mathrm{O}_{2} \mathrm{~min}^{-1} \mathrm{mg}^{-1}$ protein-plotted against the reciprocal of the absolute temperature).

\section{EXPERIMENTAL RESULTS}

\section{Selection for chilling resistance}

Data derived from selection experiments not involving the application of the mutagen are presented in Table 1. The appearance of individual petri dishes from certain of the treat-

T A B L 1. Cell lines isolated from petri dish plates following exposure of the plates to chilling temperatures for 21 days

\begin{tabular}{|c|c|c|c|c|c|}
\hline \multirow{2}{*}{$\begin{array}{l}\text { Parent cell } \\
\text { suspension line }\end{array}$} & \multirow{2}{*}{$\begin{array}{l}\text { Plating Density } \\
\text { cells } \mathrm{ml}^{-1} \times 10^{-3}\end{array}$} & \multicolumn{4}{|c|}{ Mean number of colonies per plate* } \\
\hline & & $\begin{array}{l}\text { Controlt } \\
\text { (plates not chilled) }\end{array}$ & $\begin{array}{l}\text { Chilled } \\
5^{\circ} \mathrm{C}\end{array}$ & $\begin{array}{l}\text { Chilled } \\
0^{\circ} \mathrm{C}\end{array}$ & $\begin{array}{l}\text { Chilled } \\
-3^{\circ} \mathrm{C}\end{array}$ \\
\hline $\begin{array}{l}\text { N. syluestris } \\
\text { (H.9) }\end{array}$ & $\begin{array}{l}10 \\
20 \\
20 \\
50\end{array}$ & $\begin{array}{l}49 \\
164 \\
351\end{array}$ & $\begin{array}{l}- \\
-\end{array}$ & $\begin{array}{r}22 \\
68 \\
102\end{array}$ & $\begin{array}{l}0 \\
2 \cdot 4 \\
4 \cdot 5\end{array}$ \\
\hline $\begin{array}{l}\text { N. sylvestris } \\
\text { (D) }\end{array}$ & $\begin{array}{l}10 \\
20 \\
50\end{array}$ & $\begin{array}{r}88 \\
208 \\
387\end{array}$ & 二 & $\begin{array}{r}64 \\
84 \\
139\end{array}$ & $\begin{array}{r}0 \\
0 \\
20\end{array}$ \\
\hline $\begin{array}{l}\text { C. annutum } \\
\text { (C) }\end{array}$ & 20 & 541 & $9 \cdot 4$ & - & - \\
\hline
\end{tabular}

* Colonies on ten plates counted after 6 weeks (C. annuum) or 8 weeks ( $N$. syloestris) incubation at $25^{\circ} \mathrm{C}$ following chilling.

$\dagger$ Colonies counted after 4 weeks (C. annwum) or 6 weeks ( $N$. syloestris) incubation. 
ments in this experiment are illustrated at the time of colony counting in Plate 1. Cell lines were grown up for further testing from individual colonies developing in $N$. sylvestris following chilling at $-3{ }^{\circ} \mathrm{C}$ and from $C$. annurm following chilling at $5^{\circ} \mathrm{C}$.

Data derived from chilling experiments involving treatment with the mutagen, EMS prior to plating are shown in Table 2. Cell lines were recovered as described above. Only in the case of $C$. annuum was there an indication of an increase in the number of recoverable colonies as a consequence of the EMS treatment.

T A B LE 2. Cell lines isolated from petri dish plates following exposure of suspensions to EMS for $60 \mathrm{~min}$. and incubation of plates at chilling temperatures for 21 days

\begin{tabular}{|c|c|c|c|c|c|c|}
\hline \multirow{2}{*}{$\begin{array}{l}\text { Parent cell } \\
\text { suspension line }\end{array}$} & \multirow{2}{*}{$\begin{array}{l}\text { Plating Density } \\
\text { cells } \mathrm{ml}^{-1} \times 10^{-3}\end{array}$} & \multirow{2}{*}{$\begin{array}{l}\text { EMS } \\
\text { percentage } \\
\mathrm{v} / \mathrm{v}\end{array}$} & \multicolumn{4}{|c|}{ Mean number of colonies per plate* } \\
\hline & & & Control & $\begin{array}{l}\text { Chilled } \\
\left(5^{\circ} \mathrm{C}\right)\end{array}$ & $\begin{array}{l}\text { Chilled } \\
\left(0^{\circ} \mathrm{C}\right)\end{array}$ & $\begin{array}{l}\text { Chilled } \\
\left(-3^{\circ} \mathrm{C}\right)\end{array}$ \\
\hline $\begin{array}{l}\text { N. sylbestris } \\
\text { (H.9) }\end{array}$ & 10 & $\begin{array}{l}0 \\
0.075 \\
0.3 \\
1.5\end{array}$ & $\begin{array}{c}56 \\
37 \\
9 \cdot 4 \\
6.2\end{array}$ & $\begin{array}{l}- \\
-\end{array}$ & $\begin{array}{r}29.0 \\
4.0 \\
2.2 \\
1.4\end{array}$ & $\begin{array}{l}0-2 \\
0-3 \\
0 \\
0\end{array}$ \\
\hline $\begin{array}{l}\text { N. syluestris } \\
\text { (D) }\end{array}$ & 10 & $\begin{array}{l}0 \\
0-3 \\
1.5\end{array}$ & $\begin{array}{l}95 \\
47 \\
20\end{array}$ & - & $\begin{array}{l}69 \\
33 \\
14\end{array}$ & $\begin{array}{l}0.4 \\
0-1 \\
0-5\end{array}$ \\
\hline $\begin{array}{l}\text { C. annuum } \\
\text { (C) }\end{array}$ & 20 & $\begin{array}{l}0 \\
0.3 \\
0.75 \\
1.5\end{array}$ & $\begin{array}{r}582 \\
146 \\
122 \\
13\end{array}$ & $\begin{array}{l}13 \\
17 \\
21 \\
0.8\end{array}$ & $\begin{array}{l}0 \\
0 \\
0 \\
0\end{array}$ & $\begin{array}{l}- \\
- \\
-\end{array}$ \\
\hline
\end{tabular}

* Footnotes as Table 1.

Incidence of retention of chilling resistance in the cell lines obtained following the selection procedure

The cell lines recovered following the selection experiments described above were grown into callus cultures and then tested for chilling resistance in the callus survival test (see Materials and Methods) when compared with cell lines isolated by plating the parent cell lines at $25^{\circ} \mathrm{C}$ (non-selected cell lines). The results are summarized in Table 3 . With $N$.

T А В В 3 . Summary of results of the callus survival test applied to cell lines recovered by the selection procedure. N. sylvestris callus fragments chilled at $-3^{\circ}$ and those of $\mathrm{C}$. annuum at $5^{\circ} \mathrm{C}$ for 21 days before transfer to $25^{\circ} \mathrm{C}$ to test for resumption of growth

\begin{tabular}{llll}
\hline $\begin{array}{l}\text { Parent cell line } \\
\text { from which lines } \\
\text { selected }\end{array}$ & $\begin{array}{l}\text { EMS concentration } \\
\text { (\%) used prior to } \\
\text { selection procedure }\end{array}$ & $\begin{array}{l}\text { Number of cell } \\
\text { lines tested }\end{array}$ & $\begin{array}{l}\text { Number showing } \\
\text { some recovery }\end{array}$ \\
\hline $\begin{array}{lll}\text { N. syloestris } \\
\text { (H.9) }\end{array}$ & 0 & 9 & 2 \\
& 0.075 & 1 & 0 \\
N. syloestris & 1.5 & 1 & 1 \\
(D) & 0 & 16 (non-selected) & 3 \\
& 0.3 & 16 & 5 \\
C. annuum & 1.5 & 11 & 7 \\
(C) & 0 & 7 & 1 \\
& 0.75 & 17 (non-selected) & 4 \\
& & 23 & 5 \\
\hline
\end{tabular}


sylvestris of the 25 cell lines selected without mutagen treatment 7 (28 per cent) showed growth of individual callus fragments in this callus survival test. The corresponding survival percentages were for lines selected following mutagen treatment (20 lines) 45 per cent and for the non-selected lines ( 36 lines) 19 per cent. With $C$. anmurm the corresponding survival percentages were 29,39 and 0 .

Callus fragments showing re-growth from five cell lines of $N$. sylvestris and from seven lines of $C$. annurum in this callus survival test were grown up and used to prepare suspension cultures which were then submitted to the plating selection procedure (no mutagen treatment included) and compared with the parent suspension cultures and with a suspension from a non-selected line of $C$. annuzum. The lines chosen were those which showed good survival in the callus test as indicated by the number of callus fragments showing regrowth on return to $25^{\circ} \mathrm{C}$. The results are described in Table 4 (which also indicates whether the cell lines had been initially obtained in a selection test with or without the use of the mutagen). Two of the $N$. sylvestris lines (NV 14 and NV 35) and two of $C$. annurum lines (CV 34 and CV 45) had clearly retained a significant level of chilling resistance. All four of these lines had been selected following treatment with the mutagen. By contrast the $N$. sylvestris line NV 16 and the $C$. annurm lines CV 11, CV 33 and CV 14 showed no retention of resistance.

T A В L E 4. Survival following chilling of plates inoculated (plating density $20 \times 10^{3}$ cells $\mathrm{ml}^{-1}$ ) with suspension cultures derived from cell lines which showed good recovery in the callus survival test. Plates chilled for 21 days at $-3^{\circ} \mathrm{C}$ (N. sylvestris) or $5^{\circ} \mathrm{C}$ (C.annuum)

\begin{tabular}{|c|c|c|c|c|}
\hline \multirow{2}{*}{$\begin{array}{l}\text { Parent cell } \\
\text { line }\end{array}$} & \multirow{2}{*}{$\begin{array}{l}\text { Cell line } \\
\text { reference no. }\end{array}$} & \multirow{2}{*}{$\begin{array}{l}\text { EMS }(\% v / v) \\
\text { used prior to } \\
\text { initial selection }\end{array}$} & \multicolumn{2}{|c|}{ Mean number of colonies per plate* } \\
\hline & & & $\begin{array}{l}\text { Control } \\
\text { (Plates not chilled) }\end{array}$ & Chilled \\
\hline $\begin{array}{l}\text { N. syloestris } \\
\text { (H.9) }\end{array}$ & $\begin{array}{l}\text { NV } 16 \\
\text { NV } 14 \\
\text { H.9 (parent) }\end{array}$ & $\begin{array}{l}0 \\
1 \cdot 5 \\
-\end{array}$ & $\begin{array}{r}68 \\
167 \\
173\end{array}$ & $\begin{array}{c}4 \cdot 2 \\
54 \\
3 \cdot 2\end{array}$ \\
\hline $\begin{array}{l}\text { N. syloestris } \\
\text { (D) }\end{array}$ & $\begin{array}{l}\text { NV } 61 \\
\text { NV } 23 \\
\text { NV } 35 \\
\text { D (parent) }\end{array}$ & $\begin{array}{l}0 \\
0 \\
0-3 \\
-\end{array}$ & $\begin{array}{l}152 \\
124 \\
212 \\
203\end{array}$ & $\begin{array}{l}16 \\
21 \\
93 \\
10\end{array}$ \\
\hline $\begin{array}{l}\text { C. armulum } \\
\text { (C) }\end{array}$ & $\begin{array}{l}\text { CV } 11 \\
\text { CV } 14 \\
\text { CV } 33 \\
\text { CV } 34 \\
\text { CV } 36 \\
\text { CV } 44 \\
\text { CV } 45 \\
\text { C (parent) } \\
\text { C } 9 \text { (non-selected) }\end{array}$ & $\begin{array}{l}0 \\
0 \\
0.75 \\
0.75 \\
0.75 \\
0.75 \\
0.75 \\
- \\
-\end{array}$ & $\begin{array}{l}370 \\
482 \\
324 \\
528 \\
503 \\
476 \\
512 \\
489 \\
425\end{array}$ & $\begin{array}{c}4 \cdot 3 \\
27 \\
0 \cdot 2 \\
124 \dagger \\
45 \\
38 \\
137 \\
11 \\
21 \dagger\end{array}$ \\
\hline
\end{tabular}

- See footnotes to Table 1.

† Used for studies on respiratory activity of isolated mitochondria.

Respiratory activity of mitochondria isolated from a chilling resistant ( $C V$ 34) and a chilling sensitive $(C 9)$ cell line of $C$. annuum

The relationship between $\mathrm{O}_{2}$ uptake and temperature as shown in the Arrhenius plots [Fig. 1(a) and (b)] shows a differential response of the mitochondria isolated from the chilling resistant compared to the chilling sensitive cell line. The chilling resistant line showed a linear response for both state 3 and state 4 respiration over the range $5-20^{\circ} \mathrm{C}$. With the chilling sensitive line there was, with both types of respiration, a sharp transition 

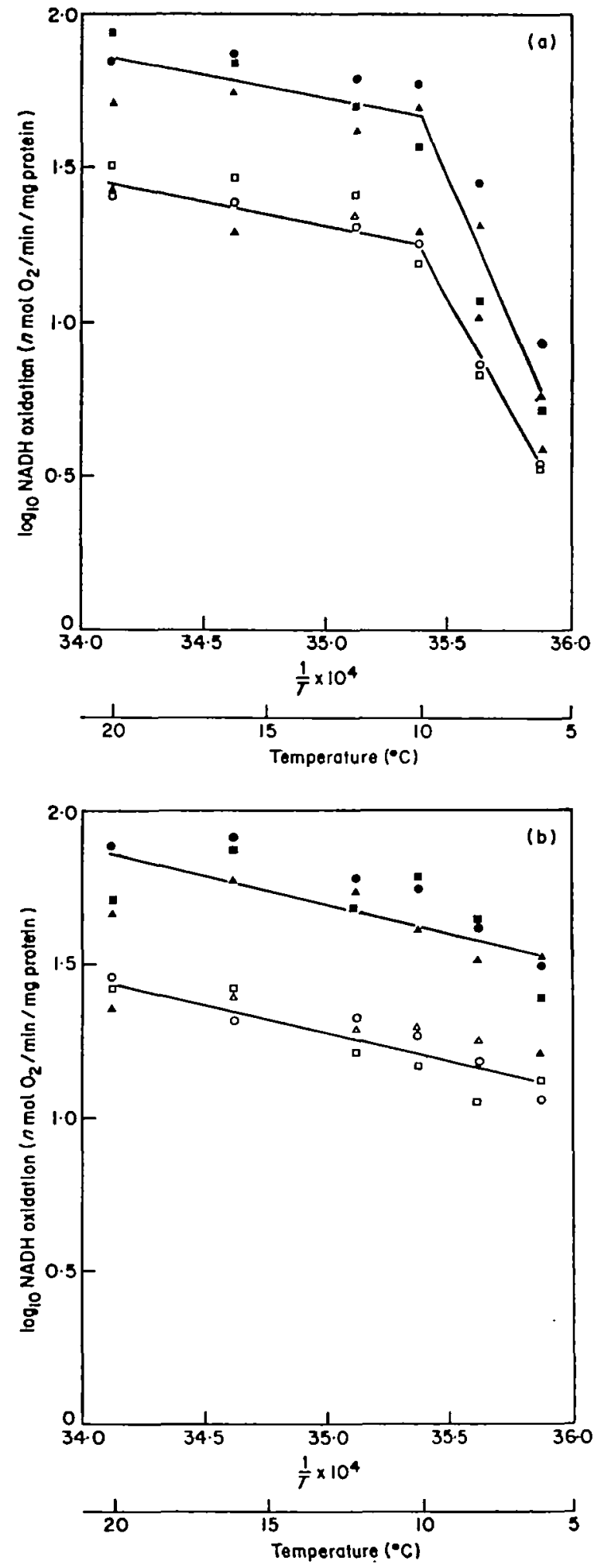

Fro. 1. Arrhenius plots for NADH oxidation by mitochondria isolated from the non-selected cell line (C 9) [Fig. I(a)] and for the chilling resistant cell line (CV 34) [Fig. I(b)]. Different-shaped symbols represent results from three different experiments. Closed symbols for state 3 respiration, open symbols for state 4 respiration. 
to a steeper slope (corresponding to a higher activation energy, $\mathrm{Ea}$ ) when the temperature fell to $10^{\circ} \mathrm{C}$.

\section{DISCUSSION}

The selection procedure adopted required cells to survive a period at low temperatures and then resume growth on return to $25^{\circ} \mathrm{C}$ leading to the development of colonies capable of subculture. The duration and temperature adopted for the chilling treatment, in the case of each species, was such that only a small proportion of the cells survived. Some of the cell lines isolated by this procedure showed no enhanced survival expectation when resubmitted to the selection pressure after a period of growth at $25^{\circ} \mathrm{C}$; others retained a high level of resistance through two periods of growth each of 3-4 weeks. These lines which retained their chilling resistance were obtained from selection experiments in which the mutagen, EMS, was applied to the cell suspensions prior to plating. The use of the mutagen enhanced the number of initial cell lines which could be isolated from suspensions of $C$. annuum.

It is considered that these lines retaining chilling-resistance probably are by selection of genetic modifications conferring resistance to the selection pressure. The comparative study on the respiration of mitochondria derived from one of these lines with those from a non-selected line strongly suggests that the genetic modification(s) selected directly concern aspects of cellular metabolism related to the chilling resistance in whole plants. A similar contrast in the Arrhenius plots has been recorded in comparisons between mitochondria isolated from a number of chilling resistant and chilling sensitive species (Lyons and Raison, 1970). The site of the difference is considered to be located in the mitochondrial membrane where the lipoprotein is on the borderline of a reversible phasetransition from a liquid-crystalline structure to a coagel and where the temperature at which the phase change occurs is related to the degree of saturation of the hydrocarbon chains of the lipid components (Luzzati and Husson, 1962; Lyons, Wheaton and Pratt, 1964; Yamaki and Uritani, 1974). A more critical test of this must however await the derivation of plants from the resistant cell lines, then multiplication by selfing and the demonstration of enhanced chilling resistance in the progeny. This is possible with the $N$. sylvestris cell lines where shoot bud initiation can be induced by sub-culture to a medium lacking 2,4-D.

The isolation of cell lines, via the selection procedure, which showed no retention of chilling resistance or which after survival in the callus test showed no resistance when again tested by chilling of plated cells suggests that the cell populations contained cells which differed in their physiology sufficiently to enable a small fraction to survive the chilling stress. Such cells when grown at $25^{\circ} \mathrm{C}$ would again give cell populations with a similar range of physiological states to that present in the parent culture. A recent study (Bayliss, 1976) with carrot cell suspension cultures has indicated that these cells have a wide spread of cell cycle times. For instance in a culture with a mean generation time of $50 \mathrm{~h}$, the range of cell cycle times embracing 80 per cent of the cells was from 21 to $82 \mathrm{~h}$. Presumably since these carrot cultures did not change in mean generation time over many sub-cultures we are not dealing with a mixed population from which a fast-growing fraction can be selected, rather each cell lineage fluctuates from division to division in its cycle time. It has also been demonstrated that extension of cell cycle time in carrot (Bayliss, 1975) and sycamore cell cultures (Gould, Bayliss and Street, 1974) involves predominantly expansion of the Gl component of the cell cycle. These observations indicate, that in cell suspension cultures, individual cells differ from one another in metabolic activity and that when growth is stopped or reduced to a very low level by chilling then the cells will be arrested in different phases of the cell cycle (slower growing cells being more likely to be arrested in G1). Thus the cells would be expected to differ in their sensitivity to killing by a prolonged period at a chilling temperature. Survival of the chilling procedure here 


\section{0}

adopted might therefore be expected to reflect the physiological state of the surviving cells at the time of application of the chilling temperature, with survival being enhanced in cells which have undergone an appropriate genetic change. Hence some of the surviving cells would on re-growth give rise to populations identical with the parent culture, others with genetically-modified metabolism to cell lines showing a stable change in chilling resistance.

\section{ACKNOWLEDGEMENTS}

Grateful acknowledgement is made to the Science Research Council for a CAPS Studentship with Unilever Laboratories which enabled one of us (P.J.D.) to participate in this work, and to Dr Laurie Jones of Unilever Laboratories for many helpful discussions and to Dr W. Cockburn for advice in the studies with isolated mitochondria.

\section{LITERATURE CITED}

BAyLuss, M. W., 1975. The duration of the cell cycle in Daucus carota L in vivo and in vitro. Expl Cell Res. 92, 31-8.

- 1976. Variation in the cell cycle duration within suspension cultures of Daucus carota and its consequence for the induction of ploidy changes with colchicine. Protoplasma.

BnDING, H., 1974. Mutation in haploid cell cultures. In Haploids in Higher Plants ed. K. J. Kasha, pp. 323-7. University of Guelph.

Chance, B. and Williams, G. R., 1955. Respiratory enzymes in oxidative phosphorylation I. Kinetics of oxygen utilization. J. biol. Chem. 217, 383-93.

DTx, P. J. and STREET, H. E., 1974. Effects of p-fluorophenylalanine (PFP) on the growth of cell lines differing in ploidy and derived from Nicotiana sylvestris. Pl. Scl. Lett. 3, 283-8.

1975. Sodium chloride-resistant cultured cell lines from Nicotlana sylvestrls and Capsicum annuum. Ibid. 5, 231-37.

Gould, A. R., Bayluss, M. W. and STREet, H. E., 1974. Studies on the growth in culture of plant cells. XVII. Analysis of the cell cycle of asynchronously dividing Acer pseudoplatanus L. cells in suspension culture. J. exp. Bot. 25, 468-78.

Henshaw, G. G., JhA, K. K. Mehta, A. R., Shakeshaft, D. J. and Street., 1966. Studies on the growth in culture of plant cells. I. Growth patterns in batch propagated suspension cultures. J. exp. Bot. 17, $362-77$.

HeYN, R. F., RórsCH, A. and SCHILPEROORT, R. A., 1974. Prospects in genetic engineering of plants. Q. Reo. Biophys. 7, 35-73.

LAYNE, E., 1957. Spectrophotometric and turbidometric methods for measuring proteins. I. Methods in Enzymology, ed. R. Kaplan, pp. 448-50. Academic Press, New York.

Luzzati, V. and Husson, F., 1972. The structure of the liquid-crystalline phases of lipid-water systems. J. cell. Biol. 12, 207-19.

LYONs, J. M., 1972. Phase transitions and control of cellular metabolism at low temperatures. Cryobiology 9, 341-50.

- and RAISON, J. K., (1970). Oxidative activity of mitochondria isolated from plant tissues sensitive and resistant to chilling injury' Pl. Physiol. 45, 386-9.

- WheAton, T. A. \& PratT, H. K., 1964. Relationship between the physical nature of mitochondrial membranes and chilling sensitivity in plants. Ibid. 39, 262-268.

RAISON, J. K, and LYONS, J. M. 1970. The influence of mitochondrial concentration and storage in the respiratory control of isolated plant mitochondria. Ibid. 45, 382-5.

Street, H. E., 1975. Plant cell cultures: Present and Projected Applications for Studies in Genetics. In Genetic Manipulation in Plant Materlal, ed. L. Ledoux, pp. 231-244. Plenum Press.

WIIson, S. B. 1971. Studies of the growth in culture of plant cells. XIII. Properties of mitochondria isolated from batch cultures of Acer pseudoplatanus cells. J. exp. Bot. 22, 725-34.

YamakI, S. and URTTANI, I. 1974. Mechanism of chilling injury in sweet potato. XII. Temperature dependence of succinoxidase activity and lipid-protein interaction on mitochondria from healthy and chilling stored tissue. Pl. Cell Physiol. 15, 669-80.

\section{EXPLANATION OF PLATE Plate 1}

Specimen petri dish plates of $N$. syldestris (line $\mathrm{D}$ ) from the experiment presented in Table 1 .

Plating densities: A, B, \& C $=20 \times 10^{3}$ cells ml ${ }^{-1} ; \mathrm{D}=50 \times 10^{3}$ cells ml-1.

A. Control: incubated for 6 weeks at $25^{\circ} \mathrm{C}$.

B. Chilled to $0{ }^{\circ} \mathrm{C}$ for 3 weeks prior to incubation for 8 woeks at $25^{\circ} \mathrm{C}$.

C, D. Chilled to $-3^{\circ} \mathrm{C}$ for 3 weeks prior to incubation for 8 weeks at $25^{\circ} \mathrm{C}$. 


\section{DIX and STREET-Selection of Plant Cell Lines with Enhanced Chilling Resistance}
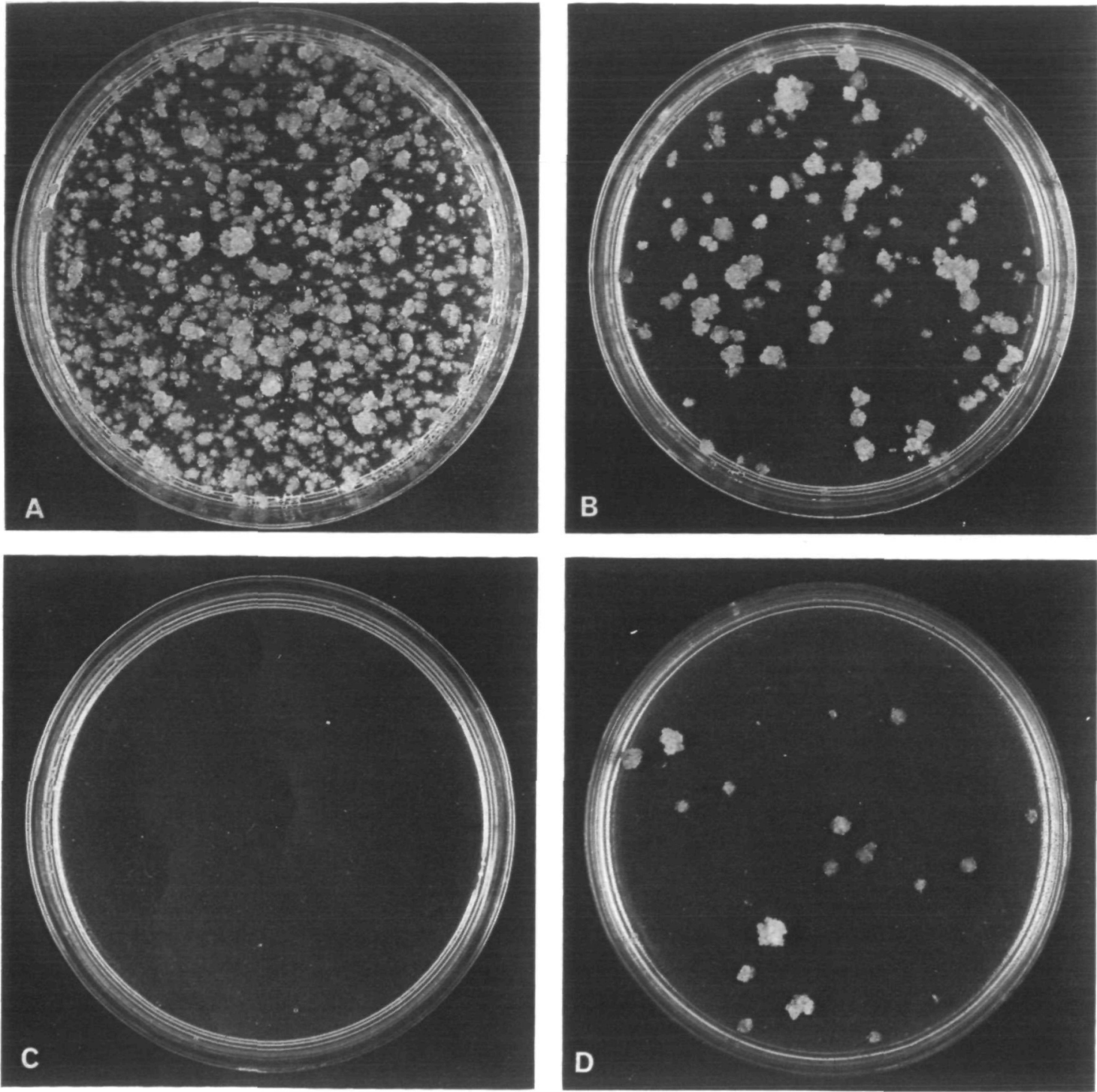

PLATE 1 
$\because$ 